
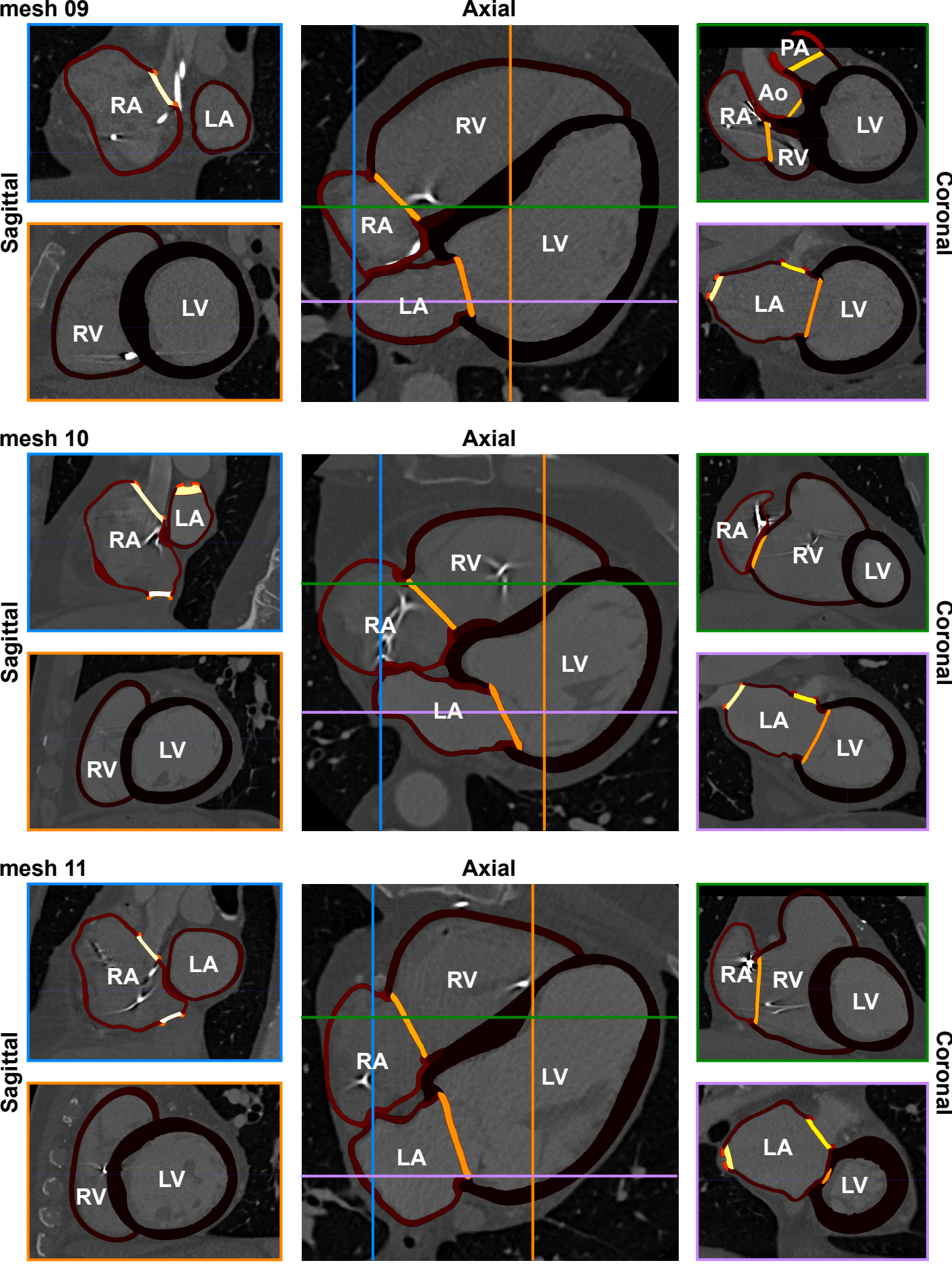

\section{mesh 12}

$\bar{~}$
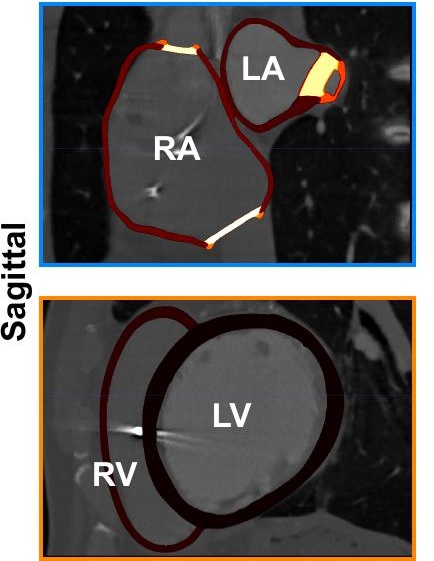

\section{Axial}

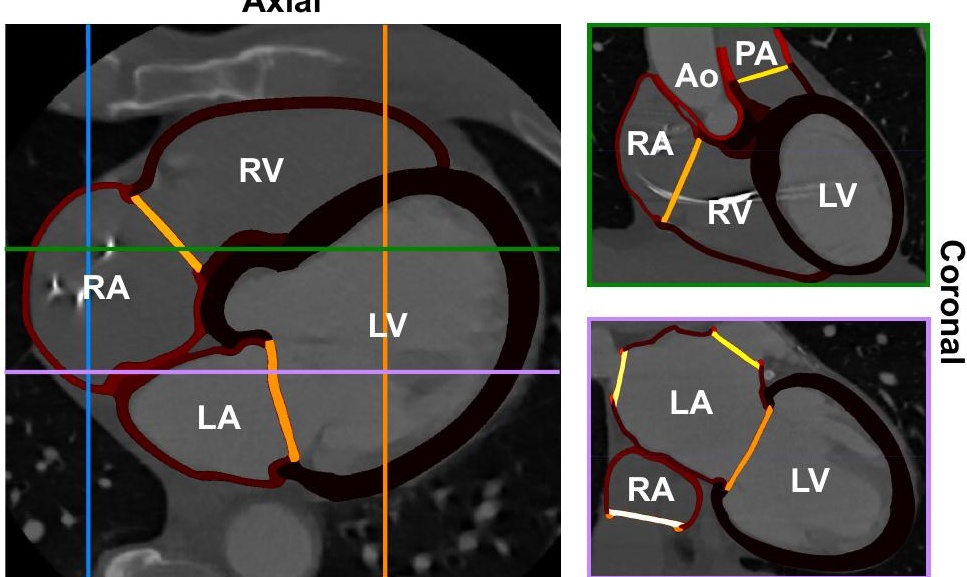

